\title{
Effect of Intraveous Tranexamic Acid and Sublingual Misoprostol on Reducing Post Cesarean Section Bleeding
}

\author{
SAEEDA SAFI ${ }^{1}$, ASIA HABIB ${ }^{2}$, MOMY GUL ${ }^{3}$, GHAZALA IFTIKHAR ${ }^{4}$, SHAZIA ANWAR ${ }^{5}$ \\ ${ }^{1}$ Senior Registrar, Gynea \& Obs, Qazi Hussain Ahmad Medical Complex, Noshehra \\ ${ }^{2}$ Associate Professor, Gyne \& Obs, Qazi Hussain Ahmad Medical Complex, Noshehra \\ ${ }^{3}$ Assistant Professor, Gynae Unit- 4 Bolan Medical Complex Hospital, Quetta \\ ${ }^{4} \mathrm{HOD} \&$ Chief Consultant Gyne \& Obstetrics, Social Security Teaching Hospital, Lahore \\ ${ }^{5}$ Assistant Professor, Obstetrics \& Gynaecology, Aziz Fatimah Medical \& Dental College, Faisalabad \\ Corresponding author: Asia Habib, Email: asiahabib@gmail.com, Cell: 03005873733
}

\begin{abstract}
Background and Aim: Cesarean section rates are rising around the globe and are considered as the major surgical procedure conducted on females. Cesarean-related hemorrhage contributes to increasing mortality rates around the world. Due to the rise in cesarean rate and its associated complications, post-cesarean severe bleeding without proper management is a major concern. Therefore, the present study aimed to assess the intravenous tranexamic acid (TA) and sublingual misoprostol effect on reducing post-cesarean section bleeding.

Materials and Methods: This cross-sectional study was conducted on 146 term pregnant women undergoing emergency or elective cesarean section at the Department of Obstetrics and Gynaecology, Qazi Hussain Ahmad Medical Complex, Noshehra during the period from $7^{\text {th }}$ September 2020 to $6^{\text {th }}$ March 2021. All the participants were randomly categorized into two groups. Each group comprised of 73 participants whereas groups I and II received sublingual misoprostol $(600 \mu \mathrm{g})$ and $500 \mathrm{mg}$ intravenous tranexamic at card clamping respectively. Both groups were administrated for postoperative 48 hours and blood loss was measured. The packed cell volume and postoperative $\mathrm{Hb}$ were evaluated and compared with initial values before surgery. The need for blood transfusion, drug side effects, and additional uterotonics was evaluated. SPSS version 20 was used for data analysis.

Results: The mean age of groups I and II were $28.32 \pm 4.73$ and $28.17 \pm 4.83$ years whereas the overall mean age was $28.25 \pm 4.78$ years. A higher reduction of hemoglobin level was observed in an intravenous tranexamic group compared to the sublingual group $(-2.39 \pm 0.93$ versus $-2.09 \pm 1.28 \mathrm{~g} / \mathrm{dL})(\mathrm{p}=0.001)$. Moreover, the intravenous tranexamic group had significantly higher blood suction and gauze usage than sublingual misoprostol (256.73 \pm 83.25 versus $189.68 \pm 102.4$ cubic centimeter (cc) and $4.59 \pm 1.43$ versus $3.19 \pm 1.27$ ) for a significant value of 0.001 . The decrease in mean blood pressure during the cesarean section procedure was significant in intravenous tranexamic than sublingual misoprostol $(p=0.001)$.

Conclusion: Our study concluded that sublingual misoprostol significantly reduced total bleeding when compared to tranexamic acid. Furthermore, hemodynamic variables were stabilized more in the misoprostol group than in the tranexamic acid group. Keywords: Cesarean Section Bleeding; Intravenous Tranexamic acid; Sublingual misoprostol.
\end{abstract}

\section{INTRODUCTION}

Cesarean section rates are rising around the globe and are considered as the major surgical procedure conducted on females. Cesarean-related hemorrhage contributes to increasing mortality rates around the world [1,2]. Due to the rise in cesarean rate and its associated complications, post-cesarean severe bleeding without proper management is a major concern. Regardless of the mode of delivery, Obstetric hemorrhage is the prominent cause of maternal death globally. The prevalence of cesarean section rates varied from $20 \%$ to $30 \%$ in developed countries [3]. Pakistan exemplifies the magnitude of the problem. During caesarean section, average blood loss is two time higher than vaginal delivery, the rising prevalence of caesarean section has contributed to postpartum hemorrhage (PPH) [4]. Though oxytocin value in post-vaginal birth PPH reduction is well established, little attention has been given to their value cesarean section. The benefits of oxytocin are observed during vaginal birth have been assumed to apply to cesarean section. However, it was discovered that 10 to $42 \%$ of women receiving oxytocin required additional oxytocin agents, such as prostaglandins and ergot alkaloids [5]. Furthermore, in patients with prolonged labour, preeclampsia, or cardiac disease, oxytocin may not be the best agent for PPH prevention [6, 7]. Additionally, heat sensitive and light oxytocin necessitating cold storage, limiting its applications in low-resources countries [8].

Misoprostol, an injectable uterotonic agent, is used to prevent post-partum hemorrhage regardless of delivery mode (CS or vaginal) [9]. It is well absorbed when taken orally, sublingually, buccally, rectally, and vaginally [10]. When compared to other routes, a pharmacokinetic study discovered that sublingual misoprostol has the shortest time to peak concentration, the highest peak concentration, and the highest bioavailability. Following the oral and sublingual administration after 30 minutes, Peak concentration reached approximately, and 75 minutes after vaginal administration. This is because of the rapid absorption through the sublingual mucosa and the avoidance of first-pass metabolism via the liver. The abundant blood supply under the tongue, as well as the relatively neutral $\mathrm{pH}$ in the buccal cavity, could be factors. However, when compared to other routes, sublingual administration, produces the utmost Cmax, is likewise allied with the higher prevalence of side effects [11].

Another popular approach is to use the antifibrinolytic agent tranexamic acid prophylactically to reduce perioperative bleeding intravenous tranexamic. Intravenous tranexamic is a synthetic lysine derivative that acts as an antifibrinolytic agent by reversibly blocking the lysine-binding sites on plasminogen molecules. Intravenous tranexamic injection considerably reduced post placental deliveries blood loss to postpartum (2 hours) lacking thrombosis impediments, as per studies $[12,13]$. Other studies, however, have shown that when compared to routine uterotonic agents, severe PPH is caused by highly risky oral misoprostol [14]. There are limited studies regarding intravenous tranexamic and misoprostol effectiveness in post-cesarean section bleeding reduction. Therefore the present study aimed to assess the intravenous tranexamic acid (TA) and sublingual misoprostol effect on reducing post-cesarean section bleeding.

\section{MATERIAL AND METHODS}

This cross-sectional study was carried out on 146 term pregnant women undergoing emergency or elective cesarean section at the Department of Obstetrics and Gynaecology, Qazi Hussain Ahmad Medical Complex, Noshehra during the period from $7^{\text {th }}$ September 2020 to $6^{\text {th }}$ March 2021. All the participants were randomly categorized into two groups. Each group comprised of 73 participants whereas groups I and II received sublingual misoprostol $(600 \mu \mathrm{g})$ and $500 \mathrm{mg}$ intravenous tranexamic at card clamping respectively. Both groups were administrated for postoperative 48 hours and blood loss was measured. The packed 
cell volume and postoperative $\mathrm{Hb}$ were evaluated and compared to initial values before surgery. The need for additional uterotonics, blood transfusion, and drug side effects was evaluated. PPH after CS was compared between misoprostol (group-I) and intravenous TA (group-II). All the individuals with a CS indications, age's from18 to 40 years, singleton pregnancy, gestational age (37-40 weeks), spinal anesthesia, and inferior segment incision based CS were enrolled. All the women with heart, pulmonary, kidney, liver, etc. diseases, TA allergic, coagulation complaints, severe preeclampsia, abnormal placenta, PPH risk factors were excluded.

The data was statistically analyzed using SPSS version 20 software. For variables with a normal distribution, the Student's $t$ test and the paired t test were used. The repeated-measures analysis of variance test was used to examine the effect of time on the hemodynamic parameters. To compare qualitative variables between groups, the Chi-square test was used. $P$ values less than 0.05 were deemed significant.

\section{RESULTS}

The mean age of groups I and II were $28.32 \pm 4.73$ and $28.17 \pm 4.83$ years whereas the overall mean age was $28.25 \pm 4.78$ years. A higher reduction of hemoglobin level was observed in an intravenous tranexamic group compared to the sublingual group ($2.39 \pm 0.93$ versus $-2.09 \pm 1.28 \mathrm{~g} / \mathrm{dL}) \quad(p=0.001)$. Moreover, the intravenous tranexamic group had significantly higher blood suction and gauze usage than sublingual misoprostol (256.73 \pm 83.25 versus $189.68 \pm 102.4$ cubic centimeter (cc) and $4.59 \pm 1.43$ versus $3.19 \pm 1.27$ ) for a significant value of 0.001 . The decrease in mean blood pressure during the cesarean section procedure was significant in intravenous tranexamic than sublingual misoprostol $(p=0.001)$.

\begin{tabular}{|c|c|c|c|}
\hline Features & $\begin{array}{l}\text { Sublingual } \\
\text { Misoprostol }(n=73)\end{array}$ & $\begin{array}{l}\text { Intravenous } \\
\text { tranxemic } \\
(\mathrm{n}=73)\end{array}$ & P-value \\
\hline Age (year) & $28.32 \pm 4.73$ & $28.17 \pm 4.83$ & 0.796 \\
\hline $\begin{array}{l}\text { Gestational Age } \\
\text { (wks) }\end{array}$ & $39.56 \pm 1.2$ & $39.36 \pm 2.2$ & 0.512 \\
\hline $\begin{array}{l}\text { Hemoglobin before } \\
\text { intervention }(\mathrm{g} / \mathrm{dL})\end{array}$ & $12.92 \pm 1.3$ & $13.26 \pm 0.83$ & 0.034 \\
\hline $\begin{array}{l}\text { Systolic blood } \\
\text { pressure }(\mathrm{mmHg}) \\
\text { before surgery }\end{array}$ & $123.75 \pm 16.7$ & $127.38 \pm 11.21$ & 0.213 \\
\hline $\begin{array}{l}\text { Diastolic blood } \\
\text { pressure }(\mathrm{mmHg}) \\
\text { before surgery }\end{array}$ & $76.34 \pm 8.72$ & $75.36 \pm 9.81$ & 0.859 \\
\hline $\begin{array}{l}\text { Pulse rate before } \\
\text { intervention }\end{array}$ & $91.47 \pm 7.32$ & $96.28 \pm 11.52$ & 0.042 \\
\hline $\begin{array}{l}\text { Duration of } \\
\text { intervention }\end{array}$ & $39.26 \pm 1.68$ & $37.93 \pm 2.3$ & 0.07 \\
\hline
\end{tabular}

Table-2 Demographic details of Participants

\begin{tabular}{|l|l|l|l|}
\hline Features & $\begin{array}{l}\text { Sublingual } \\
\text { Misoprostol }(\mathrm{n}=73)\end{array}$ & $\begin{array}{l}\text { Intravenous } \\
\text { tranxemic }(\mathrm{n}=73)\end{array}$ & P-value \\
\hline Gauze used & $3.19 \pm 1.27$ & $4.59 \pm 1.43$ & $<0.001$ \\
\hline Blood suction cc & $189.68 \pm 102.4$ & $256.73 \pm 83.25$ & $<0.001$ \\
\hline $\begin{array}{l}\text { Hemoglobin } \\
\text { level after 48 } \\
\text { hours (g/dL) }\end{array}$ & $10.72 \pm 1.53$ & $10.71 \pm 0.98$ & 0.967 \\
\hline $\begin{array}{l}\text { Hemoglobin } \\
\text { reduction (g/dL) }\end{array}$ & $-2.09 \pm 1.28$ & $-2.39 \pm 0.93$ & $<0.001$ \\
\hline $\begin{array}{l}\text { Additional } \\
\text { uterotonics } \\
\text { required }\end{array}$ & $3(3.8 \%)$ & $4(5 \%)$ & 0.9 \\
\hline
\end{tabular}

There was no significant difference in demographic details of both groups. The gestational age and hemodynamic features before intervention showed substantial similarities with a $5 \%$ level of significance. Duration of surgery and hemoglobin levels before and after the intervention is shown in Table-1. The intravenous tranexamic group had reduced hemoglobin level significantly as compared to the sublingual misoprostol group, which shows insignificant differences after 48 hours of surgery. Additionally, as shown in Table-2 sublingual misoprostol group utilized a lower number of gauze and had blood suction compared to intravenous tranexamic. Mean blood pressure decreased significantly in the TA group as compared to sublingual misoprostol group ( $F=6.5$ (4, $514), P=0.001$ ), whereas pulse rate show similar results for both groups as shown in Table 3. Furthermore, there were no substantial dissimilarities in regards of vomiting, fever, nausea, and blood transfusion as shown Figure-1.

Table-3 details of hemodynamic details

\begin{tabular}{|c|c|c|c|}
\hline Features & $\begin{array}{l}\text { Sublingual } \\
\text { Misoprostol } \\
(\mathrm{n}=73)\end{array}$ & $\begin{array}{l}\text { Intravenous } \\
\text { tranxemic } \\
(\mathrm{n}=73)\end{array}$ & P-value \\
\hline $\begin{array}{l}\text { Mean Blood Pressure } \\
(\mathrm{mmHg}) \\
5 \mathrm{~min} \text { before spinal } \\
\text { anesthesia } \\
5 \text { min after spinal } \\
\text { anesthesia } \\
10 \text { min after spinal } \\
\text { anesthesia } \\
20 \text { min after spinal } \\
\text { anesthesia } \\
\text { Recovery room values }\end{array}$ & $\begin{array}{l}91.92 \pm 9.84 \\
88.35 \pm 9.69 \\
83.46 \pm 9.38 \\
81.78 \pm 8.87 \\
81.64 \pm 8.57\end{array}$ & $\begin{array}{l}92.69 \pm 9.43 \\
81.93 \pm 12.67 \\
78.8 \pm 10.81 \\
76.23 \pm 10.42 \\
75.8 \pm 10.32\end{array}$ & $\begin{array}{l}0.634 \\
0.01 \\
<0.001 \\
<0.001 \\
<0.001\end{array}$ \\
\hline $\begin{array}{l}\text { Pulse Rate } \\
5 \text { min before spinal } \\
\text { anesthesia } \\
5 \text { min after spinal } \\
\text { anesthesia } \\
10 \text { min after spinal } \\
\text { anesthesia } \\
20 \text { min after spinal } \\
\text { anesthesia } \\
\text { Recovery room values }\end{array}$ & $\begin{array}{l}91.82 \pm 6.71 \\
89.43 \pm 6.69 \\
87.90 \pm 6.32 \\
88.73 \pm 6.23 \\
87.32 \pm 6.67\end{array}$ & $\begin{array}{l}94.89 \pm 10.89 \\
94.46 \pm 13.08 \\
94.42 \pm 14.17 \\
94.35 \pm 14.73 \\
93.36 \pm 10.83\end{array}$ & $\begin{array}{l}0.051 \\
0.038 \\
0.002 \\
0.002 \\
0.001\end{array}$ \\
\hline
\end{tabular}

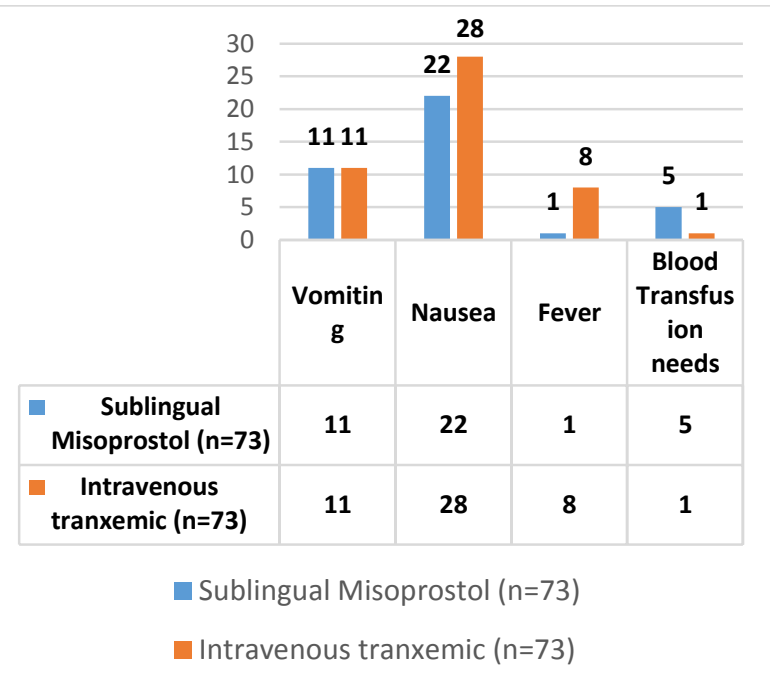

Figure-1 Prevalence of side effects in sublingual and intravenous tranxemic groups

\section{DISCUSSION}

Caesarean section is a major intervention carried out on pregnant women worldwide. Despite the oxytocin used on routine basis during CS, hemorrhage and uterine atony may experience in high risk pregnant women with severe complications. Maternal mortality can be reduced with any treatment modality. Due to widespread accessibility, economical, and room temperature stability, Misoprostol is alternative uterotonic agents [17]. Intravenous TA has been used for reducing hemorrhage after intervention and demonstrated effectiveness in patients undergoing CS [18, 19]. Blood loss at caesarean is difficult to assess accurately. A study found that visual assessment of blood loss was $33 \%$ less accurate 
than drape estimation, with the drape estimate correlating well with hot spectrometry [20]. To overcome the mentioned limitation, $\mathrm{Hb}$ level changes before intervention for few days were measured in the current study to assess blood loss indirectly.

Sahhaf et al. [21] findings contradicting the present study and found that haemoglobin levels and bleeding volume were similar in both misoprostol after 6-12 hours and intravenous TA. The disparity could be attributed to alterations in the sort and dosage of misoprostol managed. Abdel Aleem et al. [22] showed that administering misoprostol significantly reduced blood loss 10 minutes before CS matching our study findings. Sentu rk et al. [23] validated the misoprostol effects on reducing blood loss without thrombosis, which is similar to the findings of this study. According to another study conducted by Al-Sawaf et al. [24], intravenous TA appears to be less effective than intramuscular oxytocin in the prevention of $\mathrm{PPH}$; however, it has the potential advantage of being easily administered, cost-effective, and stable at room temperature.

Ugwu et al. [25] found that sublingual misoprostol (200 lg and $400 \mathrm{lg}$ ) had no effect on blood loss or PPH occurrence but the $200 \mathrm{lg}$ dose reduced hostile effects. Although sublingual misoprostol different dosages of were not utilized, it was discovered that the efficacy of sublingual misoprostol better than TA in reducing post-cesarean section bleeding loss. In future, however, researchers should increase the sample sizes to evaluate the best dose. Atukunda et al. [26] verified that at $600 \mathrm{lg}$ sublingual misoprostol is inferior for primary $\mathrm{PPH}$ protection compared to to oxytocin at $10 \mathrm{IU}$. Chaudhuri et al. [27] demonstrated that oxytocin and sublingual misoprostol both appeared to reduce PPH more efficiently as compared to oxytocin alone. Additionally, Ugwu et al. [28] found that combining intravenous oxytocin with sublingual misoprostol decreased requirement of additional uterotonics and reduced post intervention blood loss. This combination was associated with an increased risk of shivering and fever [28].

Okonofua et al. reported in another recent study that, while sublingual misoprostol is efficient in reducing certain PPH bleeding loss but not in all PPH types. Ancillary treatments and additional uterotonics are required as they reported in their study [29]. The present study found no evidence of adverse effects increase or additional uterotonics usage.

\section{CONCLUSION}

Our study concluded that sublingual misoprostol significantly reduced total bleeding when compared to tranexamic acid. Furthermore, hemodynamic variables were stabilized more in the misoprostol group than in the tranexamic acid group.

\section{REFERENCES}

1. Tabatabaie SS, Alavi A, Bazaz M. Comparison of the Effect of Tranexamic Acid and Misoprostol on Blood Loss During and After Cesarean Section: A Randomized Clinical Trial. Razavi International Journal of Medicine. 2021 Jan 1;9(1):7-13

2. Muñoz M, Stensballe J, Ducloy-Bouthors AS, Bonnet MP, De Robertis E Fornet I, et al. Patient blood management in obstetrics: prevention and treatment of postpartum haemorrhage. A NATA consensus statement. Blood Transfus 2019; 17:112.

3. Gupta M and Garg V. The rate and indications of caesarean section in a tertiary care hospital at Jaipur, India. Int J Reprod Contracept Obstet Gynecol 2017; 6:1786-1792.

4. Spahn DR, Bouillon B, Cerny V, Cerny V, Duranteau J, Filipescuet D, et al. The European guideline on management of major bleeding and coagulopathy following trauma: fifth edition. Crit Care 2019; 23:98

5. Stokes MJ, Wilkinson JP. The causes of maternal mortality are changing and preventable. BJOG 2018; 125:1262.

6. Ouh YT, Lee KM, Ahn KH, Hong SC, Oh MJ, Kim HJ, et al. Predicting peripartum blood transfusion: focusing on pre-pregnancy characteristics. BMC Pregnancy Childbirth 2019; 19:477.

7. Wang Y, Liu S, He L. Prophylactic use of tranexamic acid reduces blood loss and transfusion requirements in patients undergoing cesarean section: a meta-analysis. J Obstet Gynaecol Res 2019; 45:1562-1575. Back to cited text no. 6

8. Wudneh A, Dheresa M, Demena M. Active management of third stage of labour: practice and associated factors among obstetric care providers' at health facilities in Kambata-Tembaro Zone, Southern Ethiopia 2018. Int $\mathrm{J}$ Pregn Child Birth 2019; 5:92-97. Back to cited text no. 7

9. Saccone G, Della Corte L, D'Alessandro P, Ardino B, Carbone L, Raffone $A$, et al. Prophylactic use of tranexamic acid after vaginal delivery reduces the risk of primary postpartum hemorrhage. J Mater Fetal Neonat Med 2019; 31:1-9. Back to cited text no. 8

10. Saccone G, Caissutti C, Ciardulli A, et al. Uterine massage for preventing postpartum hemorrhage at cesarean delivery: which evidence? Eur $\mathrm{J}$ Obstet Gynecol Reprod Biol. 2018;223:64-7. https://doi.org/10.1016/j.ejogrb.2018.02.023.

11. Mannaerts D, Van der Veeken L, Coppejans H, et al. Adverse effects of carbetocin versus oxytocin in the prevention of postpartum haemorrhage after caesarean section: a randomized controlled trial. J Pregnancy. 2018; 2018:1374150. https://doi.org/10. 1155/2018/1374150.

12. Edwards HM. Aetiology and treatment of severe postpartum haemorrhage. Dan Med J. 2018;65(3)

13. Gebhardt GS, Fawcus S, Moodley J, et al. Maternal death and caesarean section in South Africa: results from the 2011-2013 Saving Mothers report of the National Committee for Confidential Enquiries into Maternal Deaths. S Afr Med J. 2017;105:287-91. https://doi.org/10.7196/SAMJ.9351.

14. Ducloy-Bouthors AS, Jeanpierre E, Saidi I, et al. TRAnexamic acid in hemorrhagic CESarean section (TRACES) randomized placebo controlled dose-ranging pharmacobiological ancillary trial: study protocol for a randomized controlled trial. Trials. 2018;19(1):149. https://doi.org/10.1186/s13063-017-2421-6.

15. Alam A, Choi S. Prophylactic use of tranexamic acid for postpartum bleeding outcomes: a systematic review and meta-analysis of randomized controlled trials. Transfus Med Rev. 2018;29(4):231-41. https://doi.org/10.1016/j.tmrv.2018.07.002.

16. Bouthors AS, Hennart B, Jeanpierre E, et al. Therapeutic and pharmacobiological, dose-ranging multicentre trial to determine the optimal dose of TRAnexamic acid to reduce blood loss in haemorrhagic CESarean delivery (TRACES): study protocol for a randomised, double-blind, placebocontrolled trial. Trials. 2018;19(1):148. https://doi.org/10.1186/s13063-0172420-7.

17. Sentilhes L, Lasocki S, Ducloy-Bouthors AS, et al. Tranexamic acid for the prevention and treatment of postpartum haemorrhage. $\mathrm{Br} J$ Anaesth. 2017;114(4):576-87. https://doi.org/10.1093/bja/ aeu448.

18. Pakniat $\mathrm{H}$, Khezri MB. The effect of combined oxytocin-misoprostol versus oxytocin and misoprostol alone in reducing blood loss at cesarean delivery: a prospective randomized double-blind study. J Obstet Gynaecol India. 2016;65(6):376-81. https://doi. org/10.1007/s13224-014-0607-3.

19. Conde-Agudelo A, Nieto A, Rosas-Bermudez A, et al. Misoprostol to reduce intraoperative and postoperative hemorrhage during cesarean delivery: a systematic review and metaanalysis. Am J Obstet Gynecol. 2017;209(1):40.e1-17. https://doi.org/ 10.1016/j.ajog.2013.03.015.

20. Othman ER, Fayez MF, El Aal DE, et al. Sublingual misoprostol versus intravenous oxytocin in reducing bleeding during and after cesarean delivery: a randomized clinical trial. Taiwan J Obstet Gynecol. 2016;55(6):791-5. https://doi.org/10.1016/j.tjog.2016. 02.019.

21. Sahhaf $F$, Abbasalizadeh S, Ghojazadeh M, et al. Comparison effect of intravenous tranexamic acid and misoprostol for postpartum haemorrhage. Niger Med J. 2018;55(4):348-53. https://doi.org/10.4103/03001652.137228

22. Abdel-Aleem H, Alhusaini TK, Abdel-Aleem MA, et al. Effectiveness of tranexamic acid on blood loss in patients undergoing elective cesarean section: randomized clinical trial. J Matern Fetal Neonatal Med. 2017;26(17):1705-9. https://doi.org/10. 3109/14767058.2013.794210.

23. Sentu "rk MB, Cakmak Y, Yildiz G, et al. Tranexamic acid for cesarean section: a double-blind, placebo-controlled, randomized clinical trial. Arch Gynecol Obstet. 2018;287(4):641-5. https://doi.org/10.1007/s00404-0122624-8.

24. Al-Sawaf A, El-Mazny A, Shohayeb A. A randomised controlled trial of sublingual misoprostol and intramuscular oxytocin for prevention of postpartum haemorrhage. J Obstet Gynaecol. 2017;33(3):277-9. https://doi.org/10.3109/01443615.2012.755503.

25. Ugwu IA, Oluwasola TA, Enabor OO, et al. Randomized controlled trial comparing $200 \mathrm{lg}$ and $400 \mathrm{lg}$ sublingual misoprostol for prevention of primary postpartum hemorrhage. Int J Gynaecol Obstet. 2016;133(2):1737. https://doi.org/10.1016/j.ijgo.2015. 09.026.

26. Atukunda EC, Siedner MJ, Obua C, et al. Sublingual misoprostol versus intramuscular oxytocin for prevention of postpartum hemorrhage in Uganda: a double-blind randomized non-inferiority trial. PLoS Med. 2018;11(11):e1001752. https://doi.org/10. 1371/journal.pmed.1001752.

27. Chaudhuri $P$, Majumdar A. Sublingual misoprostol as an adjunct to oxytocin during cesarean delivery in women at risk of postpartum hemorrhage. Int J Gynaecol Obstet. 2016;128(1):48-52. https://doi.org/10.1016/j.ijgo.2014.07.029.

28. Ugwu IA, Enabor OO, Adeyemi $A B$, et al. Sublingual misoprostol to decrease blood loss after caesarean delivery: a randomised controlled trial. J Obstet Gynaecol. 2016;34(5):407-11. https://doi.org/10.3109/01443615.2014.899329.

29. Okonofua FE, Ogu RN, Akuse JT, et al. Assessment of sublingual misoprostol as first-line treatment for primary post-partum hemorrhage: results of a multicenter trial. J Obstet Gynaecol Res. 2018;40(3):718-22. https://doi.org/10.1111/jog.12257. 